\title{
Preparing an ICT Innovation with Lectora Inspire as Teaching Media for Electrolyte and Non-Electrolyte Solutions for High School Class X
}

\author{
Widya Irfani \\ Postgraduate Program of Chemistry Education \\ State University of Medan \\ Medan, Indonesia \\ Erika Siska Yolanda Siagian \\ Postgraduate Program of Chemistry Education \\ State University of Medan \\ Medan, Indonesia
}

\author{
Nurfajriani* \\ Departement of Chemistry Education \\ State University of Medan \\ Medan, Indonesia \\ Nurfajriani@unimed.ac.id \\ Ramlan Silaban \\ Departement of Chemistry Education \\ State University of Medan \\ Medan, Indonesia \\ *Corresponding Author :
}

\begin{abstract}
This study aims to determine ICT based Lectora Inspire media as learning media for electrolyte and nonelectrolyte solutions in high schools according to national education standards board. To achieve the objectives, research development was conducted referring to ADDIE modified model. The feasibility of the media was assessed using non-test instrument with likert scale 1-4 by expert validators consist of chemistry lecturers and teachers, and data was processed using descriptive statistics. The results show that an innovative ICT learning media based on lectora inspire can be used for teaching electrolyte and non-electrolyte solution material in high school class $X$ and Innovative ICT based on lectora inspire media for electrolyte and non-electrolyte solutions obtained, had been very feasible score referring to the national education standards board, which indicated by content feasibility 3,66, language feasibilty 3,89 and presentation feasibility 3,94 .
\end{abstract}

Keywords: Lectora Inspire, ICT, Electrolyte and Non-electrolyte Solutions

\section{INTRODUCTION}

The learning process in the development of science and technology increasingly leads the use of technology to improve student achievement [1]. As a motivator and facilitator, teachers are expected to be able providing learning models and media that suitable with the learning material [2].

Chemistry learning media is one of the factors that can influence student's learning outcomes at school. The use of learning media in the study process can help teachers overcome the limitations of material delivery. Therefore, research development in learning media is needed for education purpose, with the aim to develop effective media used in schools.

Chemistry is one of the natural sciences studied at high school level. One of the most important goals of chemistry in high school is students understand the concepts, principles, laws, chemistry theories and their application to solve problems in daily life. Chemistry learning can be carried out well with the presence of interesting learning between facilitators and students [3].

From observation results using questionnaire and interviews with teacher and students for initial need assessment, it was found that there are 5 classes of X MIA in the year 2018/2019. It also known that there are still some students at high school 1 Secanggang who do not passed the minimum master criterion score.

One of the cause factors is less innovative and interactive learning media. According to the results of student's questionnaire sheets, it was found that current chemistry learning is not interactive and innovative, the students only use modul books and powerpoint, hence the students need more innovative and interactive additional supporting media such as computers and smartphones or android.

According to Rasim and Setiawan, the development of ICT learning media at schools is very good preference, especially if it uses computer-based interactive media [4]. Computerbased learning provides actives learning for both students and teachers with computer technology [5].

One of the computer technology that can be used is Lectora Inspire, an effective program for making media [6]. Lectora Inspire also will be familiar with Microsoft Office users [7].

Thus, both Lectora Inspire media and ICT based learn video can be implemented as chemical learning media for electrolyte and non-electrolyte solution material at high school 1 Secanggang. The objective of the research is to obtain Lectora Inspiring ICT-based learning media for electrolyte and non-electrolyte lesson material that match with national education standards board. ADDIE Model research used only up to development stage, because the purpose of this study is limited to develop and produce valid learning media that can be implemented based on validator assessment [8]. 


\section{RESEARCH METHODOLOGY}

The method used to achieve the objectives is research and development. This model consists of five main stages namely: (1) Need assessment of teachers and students, (2) Feasibility analysis of media used at school, (3) Designing Lectora Inspire media and ICT-based Learning videos, (4) Development of media according to designs that had been made previously, (5) Feasibility analysis of Lectora Inspire media and ICT-based learning videos that have been developed.

Media feasibility analysis use questionnaire according to modified national education standards board.

\section{RESULT}

Lectora Inspire and learning video draft is developed according to existing syllabus which has including core competencies, basic competencies, indicators and learning objectives. While the development of model is aimed for electrolyte and non-electrolyte solution lesson material.

The result of analysis, design and development stages are as follows.

A. Teacher and Student Need Assessment

The results of need assessment of teachers and students shows there is a demand of interactive and innovative learning media, students also want interactive learning video and additional media like smartphone/android that can be used anytime and anywhere.

B. Feasibility Analysis of Media Used at Schools

Current media used by school's teachers is PowerPoints. This media then assessed by two expert validators using an integrated interactive national education standards board questionnaire that has been modified. There are 3 feasibility indicators analyzed, namely (1) Content Feasibility (2) Language Feasibility and (3) Presentation Feasibility.

\section{1) Content Feasibility}

There are two aspects in content feasibility which are learning and material. The results of content feasibility assessed can be seen in Figure 1.

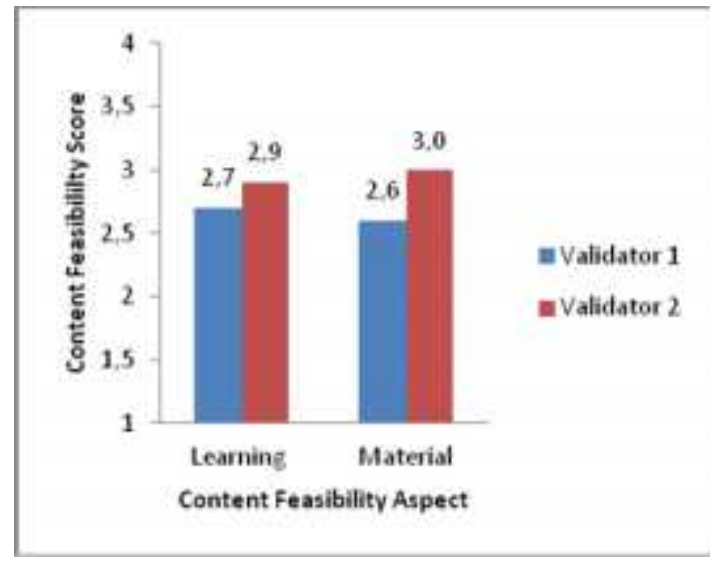

Fig 1. Content Feasibility Assessment

From Figure 1 above, it can be seen that the average score of learning aspects is 2.8 (quite feasible). This result indicates that powerpoint as school learning media is quite feasible to use in chemistry learning however it still needs some revision especially on learning aspect.

\section{2) Language Feasibility}

There are three aspects in language feasibility, namely in line with student's development, communicative and simple. The results of the language feasibility assessment can be seen in Figure 2.

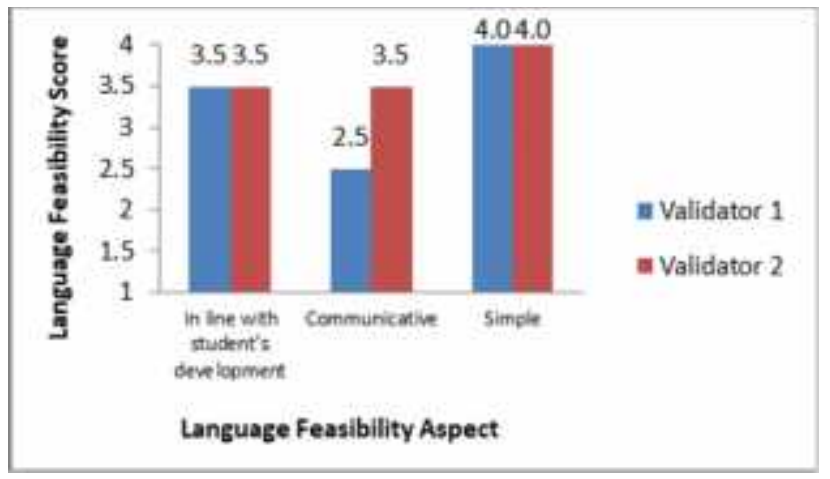

Fig 2. Language Feasibility Assessment

From Figure 2 above, it can be seen that the average score of in line with student's development aspect is 3.5 (feasible). This result indicates that language feasibility aspects include above have already feasible to use in chemistry learning

\section{3) Presentation Feasibility}

There are three aspects in presentation feasibility which are design, interface \& audio and media operation The results of the presentation feasibility assessment can be seen in Figure 3 .

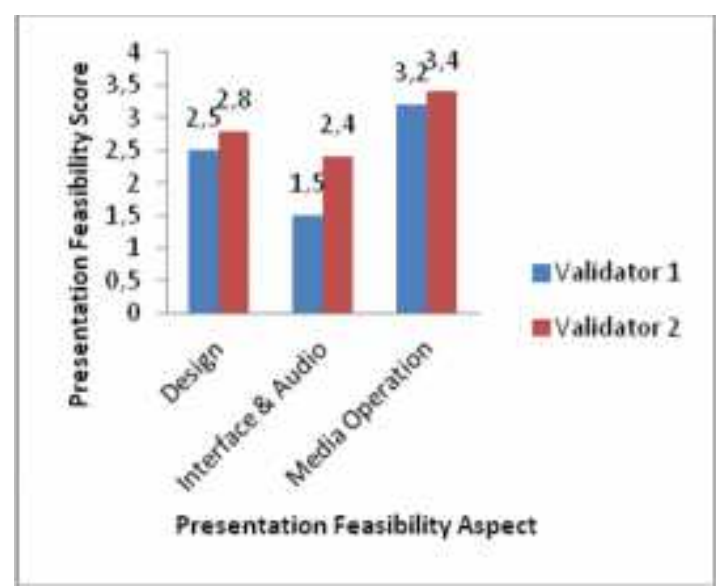

Fig 3. Presentation Feasibility Assessment

Figure 3 above shows average score of design aspects 2.6 (quite feasible). This result indicates that powerpoint media feasibility is quite feasible to use as learning media at schools according to those aspects. However, it still needs some revision and development especially in design and interface \& audio aspects. 
C. Designing Lectora Inspire Media and ICT-based Learning Videos

Desigining developed learning media (Lectora Inspire) is carried out in this stage. The workflow design or information processing for each step can be seen in flowchart visualisation below.

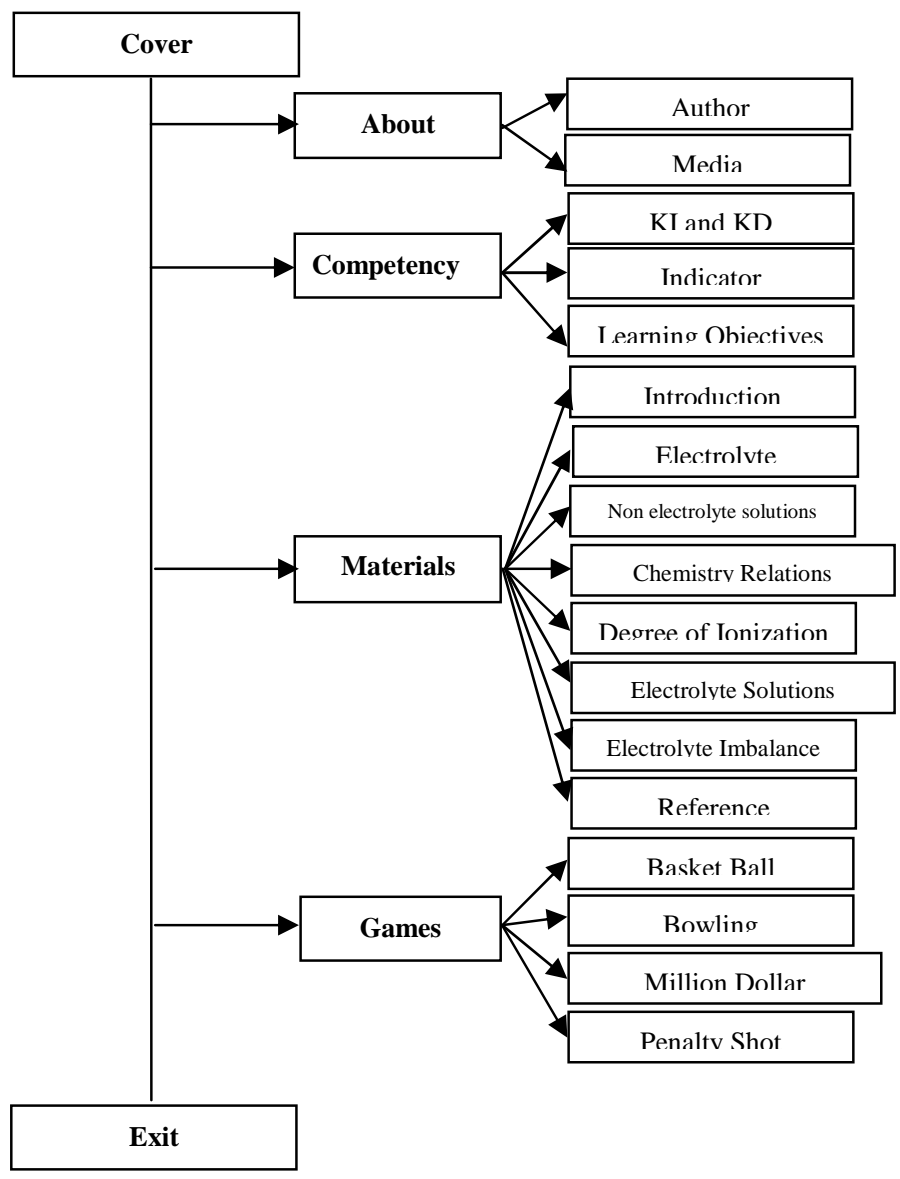

Fig 4. Flowchart Lectora Inspire Media

After Lectora Inspire media has been designed, the design results will be developed, Lectora Inspire learning video for electrolyte and non-electrolyte solution will be processed as well.

D. Development of Lectora Inspire Media and ICT-based Learning Videos

In this stage, the development of Lectora Inspire learning media (product) for electrolyte and non-electrolyte solutions is being performed. The developed components can be seen in this Table 1 below.
TABLE I. RESULF OF DEVELOPMENT COMPONENT LEARNING MEDIA

\begin{tabular}{|c|c|c|c|}
\hline \multirow[t]{2}{*}{ No } & \multirow[t]{2}{*}{$\begin{array}{c}\text { Development } \\
\text { Component/Menu }\end{array}$} & \multicolumn{2}{|c|}{$\begin{array}{c}\text { Interactive Learning } \\
\text { Media }\end{array}$} \\
\hline & & Before & After \\
\hline 1 & $\begin{array}{l}\text { Provides templates for } \\
\text { arranging material for } \\
\text { electrolyte and non- } \\
\text { electrolytic solutions }\end{array}$ & Yes & Yes \\
\hline 2 & $\begin{array}{l}\text { Provides media usage } \\
\text { instructions menu (icon } \\
\text { / button / logo) }\end{array}$ & No & Yes \\
\hline 3 & Provides profile menu & No & Yes \\
\hline 4 & $\begin{array}{l}\text { Provides competency } \\
\text { menu }\end{array}$ & No & Yes \\
\hline 5 & Provides material menu & No & Yes \\
\hline 6 & $\begin{array}{l}\text { Examples of electrolyte } \\
\text { and non-electrolyte } \\
\text { solutions }\end{array}$ & No & Yes \\
\hline 7 & $\begin{array}{l}\text { Simulation animation of } \\
\text { electrolyte and non- } \\
\text { electrolyte solution } \\
\text { experiments }\end{array}$ & No & Yes \\
\hline 8 & Video on Media & No & Yes \\
\hline 9 & Audio on Media & No & Yes \\
\hline 10 & Animation on Media & No & Yes \\
\hline 11 & Images on Media & Ada & Yes \\
\hline 12 & Games Menu & No & Yes \\
\hline 13 & Reference Menu & No & Yes \\
\hline
\end{tabular}

E. Feasibility Analysis of Developed Media

Lectora Inspire media and ICT-based learning videos that have been developed then assessed by three expert validators using integrated interactive national education standards board questionnaire that has been modified. There are 3 feasibility indicators, namely (1) Content Feasibility (2) Language Feasibility and (3) Presentation Feasibility

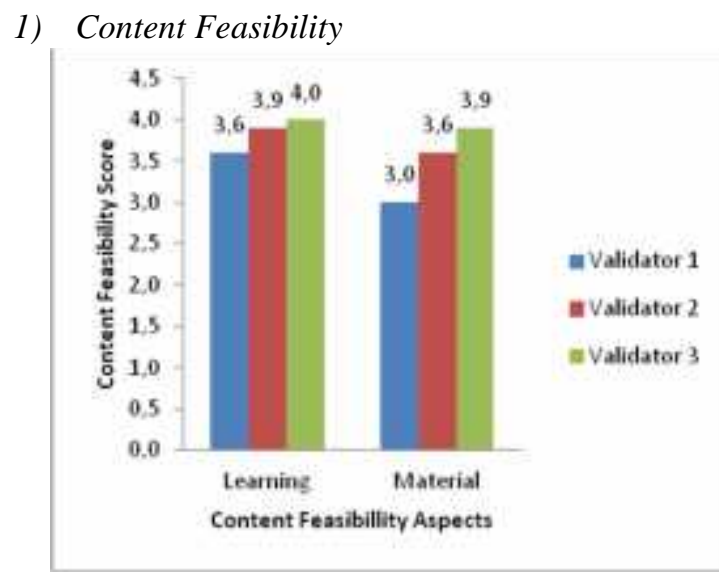

Fig 5. Content Feasibility Assessment

Average mean score from all aspects for content feasibility consist of learning and material is 3.66 (very feasible). 


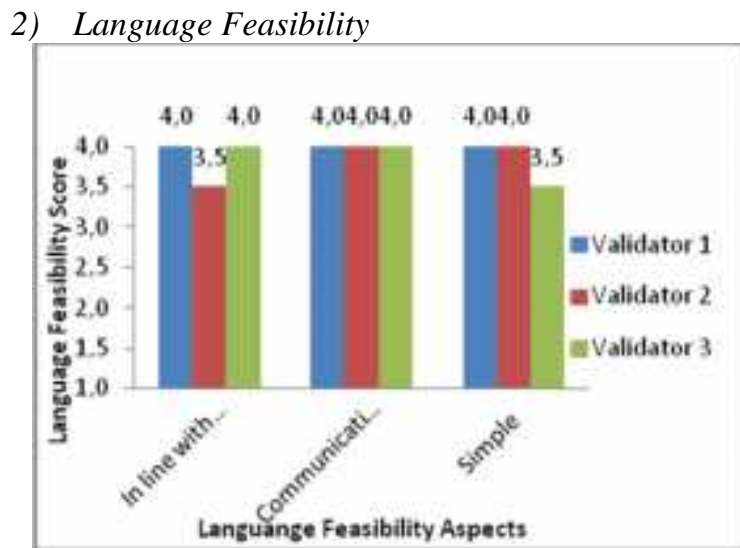

Fig 6. Language Feasibility Assessment

Average mean score of overall aspects for languange feasibility consist of in line with student's development, communication and simple is 3.89 (very feasible)

3) Presentation Feasibility

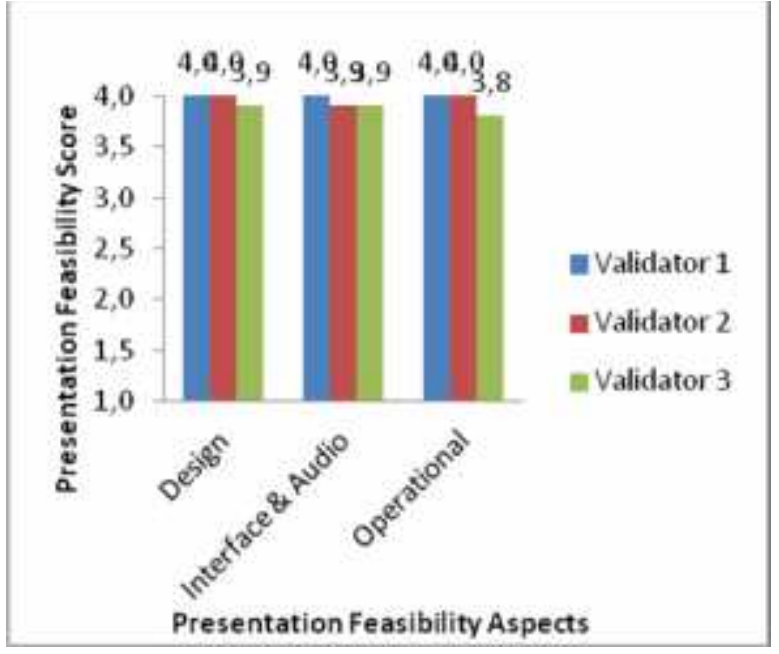

Fig 7. Presentation Feasibility

Average mean score from overall apects including design, interface \& audio and operational media is 3.94 (very feasible)

\section{DISCUSSION}

Product that produced from this development research is CD (Compact Disk) and Android Apk, which designed and made by the researchers with the aim to become a chemistry learning media for electrolyte and non-electrolyte solutions that can be used by teachers and students anytime and anywhere. This development research began with the need assessment stage and analysis of current media used at high school 1 Secanggang. When results obtained, the next step was designing Lectora Inspire media and ICT-based learning video with Flowchart. Afterwards, final design draft was developed with the analyzed components. After the media is developed and already in Lectora Inspire media state, the next step was conducted feasibility analysis with help from expert validator using modified national education standards board. From there, some revisions of the model were conducted, then Lectora Inspire media is produced. From this media, we created chemistry learning video for electrolyte and nonelectrolyte solution material

Furthermore, the results of feasibility analysis conducted by experts validator show the average mean score of content feasibility is 3.7 (very feasible), while language feasibility scored 3.9 (very feasible) and presentation feasibility obtained scored 3.9 (very feasible). This is in line with previous research conducted by Fajrina, which shows development of Lectora Inspire media with the result shows very feasible by content feasibility of 4.8 and presentation feasibility of 4.7 [9]. In addition, research conducted by Zuhri shows validation results from media experts were $87.5 \%$ and material experts were $92.5 \%$ [10].

Based on this data it can be concluded that Lectora media get good results and can be an effective learning media to support student's learning activities. Lectora inspires has several advantages compare to others, which are: (1) Lectora is user friendly, it can be used by teachers or anyone who has not (or is not) proficient in using complex programming materials; (2) Lectora is multifunctional, it can create websites, interactive learning content, and create presentations for product or company profiles; (3) The features provided by Lectore Inspire greatly facilitate the novice users in create multimedia (audio and video) learning; (4) The Lectora template is quite complete; (5) Lectora Inspire provides helpful media library, (6) Lectora allows users to convert Microsoft PowerPoints presentations to e-learning content; And (7) Lectora Inspire provide 8 types of questions that are easily applied with a score at the end of the evaluation [11].

\section{CONCLUSION}

Based on the results of data analysis and discussion on the conducted research, it can be concluded that (1) Current media used at school is quite feasible for chemistry learning especially for electrolyte and non-electrolyte solutions, however it still needs some revision and development. (2) Developed Lectora Inspire media and learning videos are very suitable to be used as chemistry learning media for electrolyte and non-electrolyte solution material.

\section{ACKNOWLEDGMENT}

Thanks are expressed to High School 1 Secanggang for the opportunity to conduct this research also to for granting permission to conduct research at the school.

\section{REFERENCES}

[1] Grinager, Heather. 2006. How Education Technology Leads to Improved Student Achievement. National Conference of State Legislatures. Education Issues.

[2] Nurfajriani and Z Nasution, "The Effect of Macromedia Flash Software on Learning with Cooperative Models of Team Assisted Individualization Type Towards Students' Chemistry Learning Outcomes in the Base of Thermochemical Material", Jurnal Pendidikan Kimia, vol 7(3), pp. 18-24, 2015.

[3] Yektyastuti, R dan Ikhsan, J. Development of Learning Media Based Android in Solubility Materials to Improve Academic Performance of High School Students, Jurnal Inovasi Pendidikan IPA,Volume 2 (1), 88-99. 2016.

[4] Rasim and W. Setiawan, "Development of Instructional Devices for Information Technology and Technology-Based Learning", Jurnal Pendidikan TIK, vol 1(2), pp. 1-10, 2008. 
[5] H. Akcay, A. Durmaz, C. Tüysüz, and B. Feyzioglu, "Effects of computer based learning on students' attitudes and achievements towards analytical chemistry". TOJET, The Turkish Online Journal of Educational Technology, vol 5(1), pp. 44-48, 2006.

[6] A.Faruk, "Development of Interactive Learning Media Based Lectora Inspire in Discrete Method Course. Proceeding of Internasional Conference on Research, Implimentation and Education of Mathematich And Sciences". Yogyakarta State University. 18-20 Mei 2014.

[7] S.C Wibawa, R. Harimurti, Y Anistyasari, and M.S. Sumbawati, "The Design And Implementation Of An Educational Multimedia Interactive Operation System Using Lectora Inspire", Elinvo (Electronics, Informatics, and Vocational Education), vol 2(1), pp. 74-79, 2017.

[8] N. Hasanah, R.U Rery and S. Haryati, "Development of Learning Media Based on Lectora Inspire on the Subjects of Atomic Structure and the Periodic System of Elements for Class X SMA / MA", Jurnal Online Mahasiswa (JOM) Bidang Keguruan dan Ilmu Pendidikan, 3(1), pp. 1-9, 2016.

[9] Fajrina, W, Simorangkir, M dan Nurfajriani. Developing Interactive Computer Based Learning Media of Lectora Inspire to Enhance Conceptual Skills of Senior High Schools Students. Advances in Social Science, Education and Humanities Research. Volume 200. AISTEEL 2018.

[10] M.S Zuhri, and E.A Rizaleni, "Development of Lectora Inspire with Contextual Approach to Class X Senior High School", PYTHAGORAS, vol 5(2), pp. 113- 119, 2017.

[11] M. Mas'ud, "Lectora Tutorial 1 Making Multimedia Learning With Lectora Inspire”. Yogyakarta, Pustaka Shonif, 2014. 